\title{
Exploring Management Accounting Practices in Emerging Telecommunication Market in Ghana
}

\author{
Joseph Mbawuni ${ }^{1} \&$ Anderson Ronald Anertey ${ }^{2}$ \\ ${ }^{1}$ Faculty of Business Education, University of Education, Winneba, Ghana \\ ${ }^{2}$ Scancom Ghana Limited, Northerb Business District, Kumasi, Ghana \\ Correspondence: Joseph Mbawuni, Faculty of Business Education, University of Education, Winneba, Ghana. E-mail: \\ mbawuni@gmail.com
}

Received: September 4, 2014

Accepted: September 30, 2014

Online Published: October 7, 2014

doi:10.5430/afr.v3n4p71

URL: http://dx.doi.org/10.5430/afr.v3n4p71

\begin{abstract}
The ever-increasing importance of telecommunication companies in Ghana coupled with global and domestic competitions, increasing cost and decreasing profitability was the impetus for this study. This research examines the application of a broad range of management accounting practices used by telecommunication companies in Ghana. It sought to establish the extent of use and reasons for the adoption of Management Accounting Practices (MAPs) in Ghana mobile telecom industry (GMTI). This study was a cross-sectional survey that yielded 37 useable questionnaire from respondents with varied professions in accounting and finance in MTN Ghana, a leading telecommunication company in Ghana. The findings show that the most used category of MAPs is strategic analysis practices, which has a higher relative usage rate than reported in previous research. Again, MTN Ghana uses more of traditional budgeting techniques, and relies more on financial measures than non-financial measures. The use of costing systems by MTN Ghana is quite low, prevalent among them are departmental overhead rate and Activity-based Costing. Overall, this study provides valuable understandings into the nature of MAPs applied by telecommunication companies in emerging markets in developing countries.
\end{abstract}

Keywords: Management accounting practices, Telecommunication market, Activity-based costing, Ghana

\section{Introduction}

The utilization of Management Accounting Practices (MAPs) has become more popular in today's business organizations than before, and MAPs adoption by industries has increased over the years (Abdel-Kader \& Luther, 2006; Uyar, 2010). Existing research has noted that in the early years prior to the1980's, emphasis was placed on full absorption costing, process costing, standard costing, marginal costing, break - even analysis, budgeting and budgetary control as management and cost accounting techniques for planning, controlling, evaluation, decision making and communication (Abdel-Kader \& Luther, 2006, 2008; Uyar, 2010).

Telecommunication companies in Ghana (purely multinationals) are poised to make ideal and great use of management tools or techniques that provide better and effective performances and decisions. In recent times, production and services industries are focusing more on innovative management accounting practices in a quest to overcome competition (domestic and global), profit declining, increasing in operational cost and economic crises. Management accounting practices deliver minimization of operational cost, effective performance evaluation, effective decision and control as well as meeting the challenges from global and domestic competitions (Abdel-Kadel \& Luther, 2006; James, 2012; Sharkar, Sobhan, \& Sultana, 2006).

The problem of this research stems from the fact that there is relatively little research in the area of MAP in developing countries in general and in particular in telecommunication industry. In this regard, previous research has pointed out that the application of management accounting in less developed countries remains inadequate and studies on this area are exceptional in literature (Lin \& Yu, 2002; Sleihat, Al-Nimer, \& Almahamid, 2012). Studies in management accounting have been mainly conducted in the western world (Abdel-Kader \& Luther, 2006, 2008; Uyar, 2010; Van Triest \& Elshahat, 2007). Therefore, this paper attempts to fill this gap by examining MAP in telecommunication industry in a developing country, using Ghana as the research context. This study will provide empirical evidence on the relevance and use of MAPs in the context of emerging telecommunication market in developing countries. The paper seeks to address these two objectives: 
1. To examine the extent to which management accounting practices (MAPs) are used by managers in the Ghana mobile telecommunication industry (GMTI).

2. To examine the reasons for the use of MAPs in GMTI.

\section{Literature Review}

\subsection{Previous research on MAP}

There exists a broad frame of research developed, especially after 1990s, investigating current MAPs in organizations (e.g., Chenhall \& Langfield-Smith, 1998; Joshi, 2001; Abdel-Kadel \& Luther, 2006; Sharkar, Sobhan, \& Sultana, 2006). According to Ahmad (2012), these studies were motivated largely by proclamations about the irrelevance of management accounting to current managerial needs, especially in modern manufacturing, and claims that there is a gap between management accounting theory as described in textbooks, and management accounting in practice (Drury, Braund, Osborne, \& Tayles, 1993).

Previous researches on MAPs indicate that the information on product costs generated by costing systems has a wide number of uses. These uses include, for example, pricing decisions; cost control (Van Triest \& Elshahat, 2007), an evaluation of production processes, and transfer pricing (Bjornenak, 1997). Drury et al. (1993) observed that 58 per cent of U.K firms often or always used absorption costing and in developing countries acceptance rates are similar. In India, Joshi (2001) reported that half of Indian firms adopted this technique. The use of direct (variable) costing is also widespread. Lukka and Granlund (1996) showed that 42 per cent of Finnish firms applied variable costing.

Earlier research indicates that the main functions of budgeting are planning future performance; planning the future financial position; planning future cash flows; planning future day to day operations; and controlling costs (e.g; Lyne, 1988; Chenhall \& Langfield-Smith, 1998; Sulaiman et al., 2004; Fruitticher, Laster, \& Yakhou, 2005; Abdel-Kader \& Luther, 2006). Szychta (2002), in a study in Polish firms, found that annual operating financial budgets are prepared by a significant proportion of the companies, mainly large manufacturing and service enterprises ( 80 per cent of the respondents).

\subsection{MAP measurement criteria}

Hall (2008) maintained that in recent years organizations have sought to develop more comprehensive performance measurement systems (PMS) to provide managers and employees with information to assist in managing their operations. The choice of measures to guide and evaluate the performance of business units is one of the most critical challenges facing organizations (Ittner \& Larcker, 1998).

Chartered Institute of Management Accountants (CIMA) (2005) highlighted the frameworks for performance measurement and management which are the Value-Based Management (VBM); Activity-Based Costing (ABC) and Activity-Based Management (ABM); Balanced Scorecard (BSC); European Foundation for Quality Management (EFQM) excellence model; Benchmarking; Strategic Enterprise Management (SEM); and Six Sigma. However the literature indicates that in general both financial and non-financial measures are used to measure performance (Christensen \& Nikolaev, 2013; Gomes et al., 2004).

Performance measures based on non-financial measures have been more widely applied by organizations over time (Christensen \& Nikolaev, 2013; Gomes et al., 2004; Shields, 1991). Banker et al. (2000) argued that the primary reasons suggested for the use of non-financial performance measures are that these measures are better indicators of future financial performance than accounting measures, and they are valuable in evaluating and motivating managerial performance. It has been argued that stressing financial indicators may lead to short-term thinking (e.g., Christensen \& Nikolaev, 2013; Dossi, \& Patelli, 2010).

Abdel-Kader and Luther (2006) argued that for regular or short-term decisions management accountants can use cost-volume-profit (CVP) analysis, product profitability analysis, customer profitability analysis, and stock control models. For longer-term capital investment decisions, management accountants can produce and review accounting rates of return and payback periods as well as complex signals based on discounted cash flow. The payback period method for investment evaluation is popular in most countries (e.g., Shields et al., 1991; Yoshikawa, 1994; Lazaridis, 2004; Abdel-Kader \& Luther, 2006; Hermes et al., 2007). Adoption rate as reported in the U.K by Abdel-Kader and Luther (2006) was 41 per cent which is much lower than the 84 per cent in Japan (Shields et al., 1991) and 84 per cent in China (Hermes et al., 2007).

Drury and Tayles (1994, p. 454) argues that conventional management accounting does not provide the financial information required to monitor existing strategies or support strategy formulation. Strategic analysis seeks to remedy this situation by providing the financial analysis to support the formulation of successful competitive 
advantages. Lord (1996) suggested three benefits of strategic analysis as: collection of competitor information, exploitation of cost reduction opportunities and matching of the accounting emphasis with strategic position. Guilding et al. (2000) on the contrary, highlighted 12 strategic management accounting (SMA) techniques under three categories: strategic costing and pricing attribute costing; competitor accounting; and brand value accounting. More recently, Cadez and Guilding (2008) applied five dimensions of SMA usage: (1) costing, (2) planning, control, and performance measurement, (3) strategic-decision making, (4) competitor accounting, and (5) customer accounting. Although there is strong academic support for the concept of SMA, Guilding et al. (2000) argued that, there appears to be minor use of the term: strategic management accounting in organizations and practicing accountants have a limited appreciation of what the term means.

The comparative study conducted by Joshi (2001) revealed that Indian manufacturing companies rely heavily on the traditional management accounting techniques such as variable costing, budget for day-to-day operations, capital budgeting tools, return on investment based performance evaluation, and performance evaluation. The adoption rates of newly developed practices such as shareholders' value analysis, performance evaluation (qualitative measures), product life cycle costing, back flush costing, activity based budgeting, value chain analysis, benchmarking and balanced scorecard have been rather low and slow (Abdel-Kader \& Luther, 2006; Paggios \& Pavlatos, 2009).

The findings by Paggios and Pavlatos (2009) suggest that traditional budgeting practices seem to provide higher benefits, rather than contemporary budgeting tools. Meanwhile, some studies have shown that size has a major influence in determining the adoption of newly developed cost and management accounting practices; adoption rates are much higher in larger firms (Chenhall, and Langfield-Smith, 1998; Joshi, 2001; Uyar, 2010). The use of traditional techniques remains strong according to Sulaiman, Ahmad, Alwi (2004).

\subsection{MAP in telecommunication Industry.}

The International Telecommunications Union (ITU) in their guidelines to National Regulatory Authorities (NRAs) affirmed the use of cost drivers as bases for cost allocations with much emphasis on ABC utilization. Traditional costing system used in telecommunications was full distributed cost (FDC) but was under criticism with regard to its appropriateness for managerial as well as regulatory purposes (Siguenza-guzman, Van den Abbeele, Vandewalle, Verhaaren, \& Cattrysse, 2013; Vazakidis \& Karagiannis, 2011). In this regard, Major and Hopper (2005) found that, in the telecommunication industry in Portuguese, managers perceived the implementation of $\mathrm{ABC}$ to be problematic as they found it problems about its accuracy and usefulness. Their findings revealed that while some workers resisted $\mathrm{ABC}$ by inputting inaccurate data, others had difficulty understanding $\mathrm{ABC}$, how to relate it to their jobs and had that $\mathrm{ABC}$ would add to work load. In their study, commercial managers responsible for pricing and investment rather found $\mathrm{ABC}$ very usefulness in decision making despite its problem.

Mayor (2012) also found the telecommunications managers in Marconi Telecommunication Company demanded for a change in MAP and accounting system to $\mathrm{ABC}$ for several reasons such as its usefulness and widespread acceptance by other similar companies in the telecom industry.

In Europe many companies have adopted $\mathrm{ABC}$ a fundamental management accounting system (MAS). The use of sound MAP and MAS have been highly recommended by the European Commission (EC) through legislation. In the EC, established a recommendation on Interconnection in a Liberalized Telecommuications Market on 15th October, 1997, which pointed out the importance of operators following the cost oriented principle and to implement separate cost accounting system to help effective pricing of telecommunication services.

Ghana's mobile telecommunication industry (GMTI) has witnessed enormous growth rate in recent times as a result of fierce competition among players in the industry (Nimako, Azumah, Donkor \& Adu-Brobbey, 2010; Nimako, 2012). The industry is regulated mainly by the National Communication Authority (NCA) and the Ministry of communication (MoC). In 1994, the GMTI moved from government-dominated, monopolistic industry to a liberalized competitive one. Currently, there are six mobile telecom brands and operators, namely, MTN of Scancom Ltd, Tigo of Millicom Ltd, Kasapa of Kasapa Telecom, Vodafone of Vodafone Group of Public Limited Companies, Airtel of Airtel Ghana Ltd and Glo of Globacom (NCA, 2013).

Competitive activities either domestic or global couple with economic and cost issues have become crucial concerns for the mobile telecommunication companies in Ghana. The industry is striving with the quest to maintain its competitive edge and also to run a cost effective and sound profitable venture. Research has shown that MAPs have a role in ensuring that the management of a firm is efficient and effective and may also improve performance. The dynamism and liberalization of GMTI has induced significant changes in management and control of telecommunication operations in many respects including MAPs. There is limited empirical evidence regarding the 
MAP in the telecommunication industry in general and particularly in Ghana. Therefore, this study explores MAPs in GMTI.

\subsection{Conceptual framework}

The conceptual framework for this study is based on the key MAPs dimensions identified in the existing management accounting literature. It has five main dimensions, namely, the costing system, budgeting system, performance evaluation, information for decision making and strategic analysis. The indicators for each of these dimensions are outlined in Table 2.

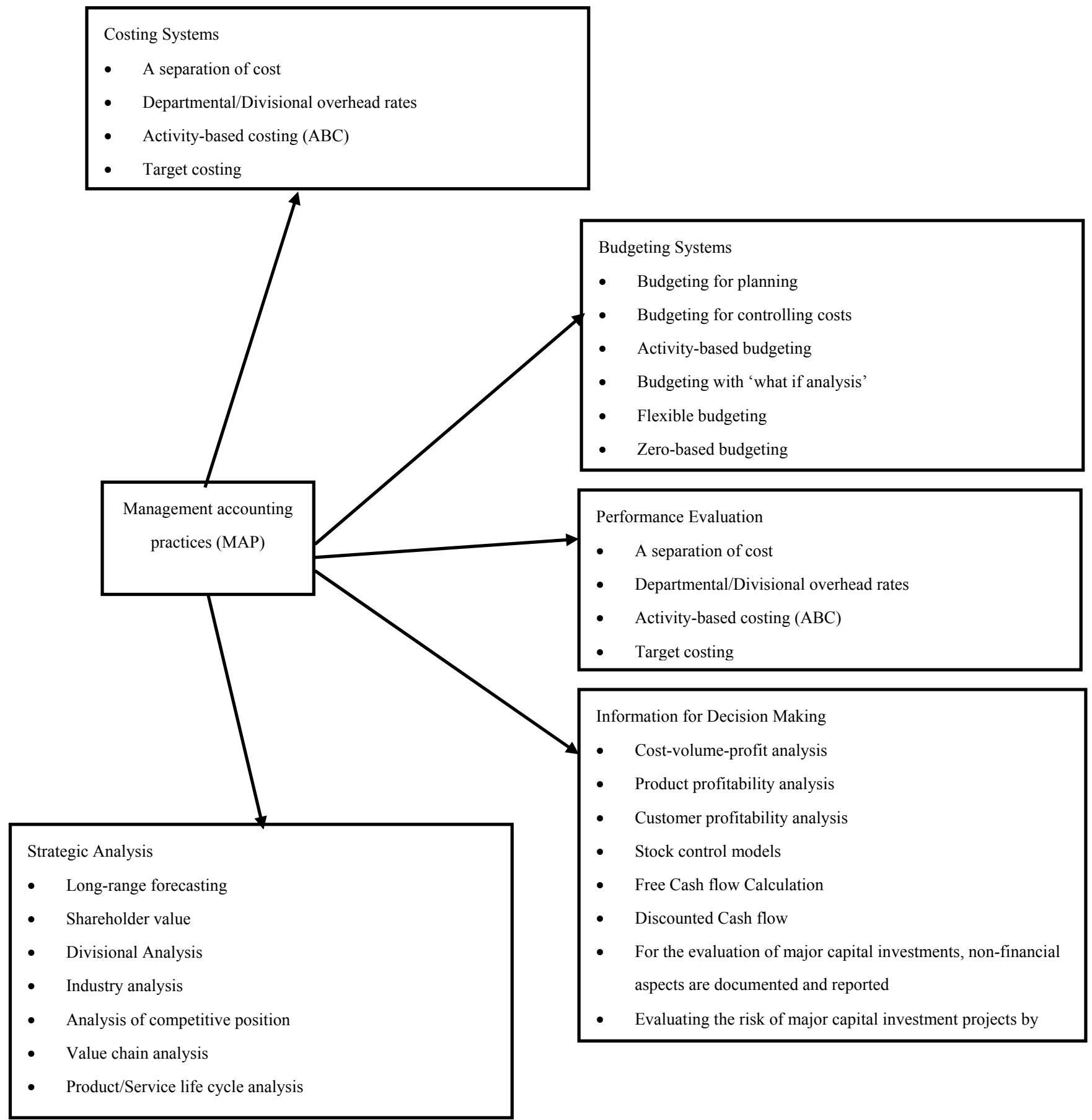

Figure 1. Key MAPs Dimensions 


\section{Methodology}

\subsection{Design, population and sampling}

This study was a cross-sectional survey that adopted a descriptive research approach since it attempted to provide an accurate account of characteristics, for instance behavior, opinions, abilities, beliefs and knowledge of a particular situation or group (Hair, Black, Babin, \& Anderson, 2010). The population of the study consisted of 300 respondents who are accounting/ finance staff of Scancom Ghana Limited, a telecommunication company, operators of MTN brand of network services in Ghana. Scancom Ghana Limited is the market share leader in the mobile telecommunication industry. A sample size of 100 was selected from the target population of 300 using convenient and purposive sampling techniques.

\subsection{Data Collection}

A self-administered structured questionnaire was designed to collect primary data from the respondents. It focused on seeking information on mainstream practices of management accounting that are relevant to the telecommunication sector. The questionnaire contained sections for respondents' profile, the use of MAPs, and reasons for the adoption of MAPs in Ghana. Responses to questions in these sections were measured through the use of Likert scales. The design of the questionnaire was made possible with survey software called "survey monkey".

Content validity refers to the extent to which an instrument represents the factors under study. To achieve content validity, questionnaire included a variety of questions on knowledge of staff members on MAPs and its usefulness. Questions were derived from previous research to ensure that they were valid in content and representative of what staff should know about MAPs and its usefulness. All persons contacted to respond to the questionnaire accepted and administered it accordingly.

A formal permission was sought from the company through the Chief Finance Officer prior to the survey. Electronic mail and direct internet survey was used in the conduct of the study. Mailing survey cannot be effective without a telephone call follow up (Cooper \& Schindler, 2006). Thus the researcher made follow up to respondents via telephone calls and consistent e-mail reminders.

The questionnaire link was sent to all targeted individuals via e-mails. The respondents were required to answer questions electronically. The questionnaire prior to the survey was pre-tested with six controllers. This was to enable the researchers refine the questions and design. The pilot questionnaire paved way for the researchers to reformat the question items. Respondents were assured of all research ethics, the rights to anonymity, confidentiality, informed consent and self-determination were recognized.

\subsection{Data Analysis tools}

The data were analysed using descriptive statistics with the aid of SPSS 16.0 for windows. The next section present the result of the study in descriptive tables using percentages and, means and standard deviations.

\section{Results}

\subsection{Respondents' profile}

The profile of the respondents are presented in Table 1. In terms of gender, majority of them (81\%) were males while few $(19 \%)$ were females. For their ages, $27 \%$ of the respondents were between the ages of 26 and 35 years, $62 \%$ of them were between 36 and 45 while about $11 \%$ of them were above 45 years.

In terms of education, majority of them (about 57\%) had bachelor's degree in accounting and finance related areas, $32 \%$ held masters' degree, $5 \%$ had Higher National Diploma (HND) and 5\% of the had other forms of education. In terms of division, $51 \%$ of the respondents are working with the finance and services, $21 \%$ are staff whose jobs are related to sales and distribution, and less than $10 \%$ of the staff's jobs related to areas such as business solutions, information technology, network groups, and human resource. In terms of job role, most of the respondents performed roles related to accounting and finance (51\%), followed by commercial, shareholder, technical and other roles. Majority of the respondents were supervisors/officers, $24 \%$ of them were managers, $16 \%$ of them were senior managers and $5 \%$ of them were general managers. 
Table 1. Respondents' profile

\begin{tabular}{|c|c|c|}
\hline Category & Frequency & Percent \\
\hline \multicolumn{3}{|l|}{ Gender } \\
\hline Male & 30 & 81.1 \\
\hline Female & 7 & 18.9 \\
\hline \multicolumn{3}{|l|}{ Age } \\
\hline $26-35$ & 10 & 27 \\
\hline $36-45$ & 23 & 62.2 \\
\hline Above 45 & 4 & 10.8 \\
\hline \multicolumn{3}{|l|}{ Educational level } \\
\hline Masters & 12 & 32.4 \\
\hline BA/Bsc/B.com & 21 & 56.8 \\
\hline HND & 2 & 5.4 \\
\hline Other & 2 & 5.4 \\
\hline \multicolumn{3}{|l|}{ Division } \\
\hline Finance and Services & 19 & 51.4 \\
\hline Sales and Distribution & 8 & 21.6 \\
\hline Corporate Services & 2 & 5.4 \\
\hline Business Solution & 1 & 2.7 \\
\hline Information Technology & 2 & 5.4 \\
\hline Network Group & 1 & 2.7 \\
\hline $\mathrm{CPG}$ & 3 & 8.1 \\
\hline Human Resource & 1 & 2.7 \\
\hline \multicolumn{3}{|l|}{ Job role } \\
\hline Accounting/Finance & 19 & 51.4 \\
\hline Commercial & 6 & 16.2 \\
\hline Stakeholder & 3 & 8.1 \\
\hline Technical & 3 & 8.1 \\
\hline Other & 6 & 16.2 \\
\hline
\end{tabular}

\subsection{The extent of use of management accounting practices}

The results of respondents' rating of extent of use of MAPs are presented in Table 2. It shows that, generally, the most used category of MAPs is Strategic Analysis representing an overall usage of 58.5\%, followed by Budgeting System (55.2\%), Performance Evaluation System (49.03\%), Costing system (46.49\%) and Information for Decision Making System (46.28\%).

\subsubsection{Costing system}

According to Table 2, an overall relative uptake of costing system was $46.49 \%$. The total uptake ranges from $21.62 \%$ to $62.16 \%$. Departmental overhead rate is the most dominant system used by respondents $(62.16 \%)$. The next most used techniques are $\mathrm{ABC}$ and separation of cost (54.05\%), target costing and transfer pricing recording overall relative usage of $40.54 \%$ and $21.62 \%$ respectively. 
Table 2. Extend of use of MAPs

\begin{tabular}{|c|c|c|c|c|c|c|}
\hline MAPs & U1 & $\mathbf{U} 2$ & U3 & U4 & U5 & U4 \& U5 \\
\hline \multicolumn{7}{|l|}{ A. Costing system (Relative usage percentage $=46.49 \%$ ) } \\
\hline A separation of cost (e.g., Fixed cost/Variable cost) & 5 & 2 & 10 & 8 & 12 & 54.05 \\
\hline Departmental/Divisional overhead rates & 2 & 2 & 10 & 9 & 14 & 62.16 \\
\hline Activity-based costing (ABC) & 4 & 1 & 12 & 11 & 9 & 54.05 \\
\hline Target costing & 9 & 5 & 8 & 12 & 3 & 40.54 \\
\hline Transfer Pricing & 11 & 10 & 8 & 5 & 3 & 21.62 \\
\hline \multicolumn{7}{|l|}{ B. Budgeting system (Relative usage $\%=55.21 \%$ ) } \\
\hline Budgeting for planning & 3 & 0 & 7 & 11 & 16 & 72.97 \\
\hline Budgeting for controlling costs & 3 & 1 & 3 & 14 & 16 & 81.08 \\
\hline Activity-based budgeting & 4 & 4 & 5 & 12 & 12 & 64.86 \\
\hline Budgeting with 'what if analysis' & 7 & 5 & 11 & 10 & 4 & 37.84 \\
\hline Flexible budgeting & 7 & 6 & 6 & 13 & 5 & 48.65 \\
\hline Zero-based budgeting & 13 & 7 & 6 & 8 & 3 & 29.73 \\
\hline Budgeting for long-term (strategic) plans & 6 & 4 & 8 & 12 & 7 & 51.35 \\
\hline \multicolumn{7}{|l|}{ C. Performance evaluation system (relative $\%=49.0 \%$ ) } \\
\hline Financial measure(s) & 3 & 3 & 3 & 15 & 13 & 75.68 \\
\hline Non-financial measure(s) related to customers & 4 & 5 & 7 & 14 & 7 & 56.76 \\
\hline Non-financial measure(s) related to operations/innovation & 4 & 4 & 10 & 12 & 7 & 51.35 \\
\hline Non-financial measure(s) related to employees & 6 & 6 & 8 & 9 & 8 & 45.95 \\
\hline Economic value added (EVA) & 10 & 9 & 9 & 7 & 2 & 24.32 \\
\hline Total Quality Management (TQM) & 10 & 8 & 7 & 7 & 5 & 32.43 \\
\hline Benchmarking & 5 & 3 & 8 & 12 & 9 & 56.76 \\
\hline \multicolumn{7}{|l|}{ D. Information for Decision (relative $\%=46.28 \%$ ) } \\
\hline Cost-volume-profit analysis & 8 & 6 & 12 & 7 & 4 & 29.73 \\
\hline Product profitability analysis & 6 & 5 & 6 & 8 & 12 & 54.05 \\
\hline Customer profitability analysis & 6 & 5 & 1 & 13 & 12 & 67.57 \\
\hline Stock control models & 5 & 4 & 9 & 8 & 11 & 51.35 \\
\hline Free Cash flow Calculation & 5 & 6 & 5 & 10 & 11 & 56.76 \\
\hline Discounted Cash flow & 6 & 9 & 9 & 8 & 5 & 35.14 \\
\hline For the evaluation of major capital investments... & 7 & 2 & 14 & 6 & 8 & 37.84 \\
\hline Evaluating the risk of major capital investment projects & 8 & 7 & 8 & 8 & 6 & 37.84 \\
\hline \multicolumn{7}{|l|}{ E. Strategic analysis (Relative usage $\%=58.48 \%$ ) } \\
\hline Long-range forecasting & 5 & 5 & 7 & 10 & 10 & 54.05 \\
\hline Shareholder value & 9 & 5 & 6 & 10 & 7 & 45.95 \\
\hline Divisional Analysis & 2 & 4 & 6 & 10 & 15 & 67.57 \\
\hline Industry analysis & 6 & 5 & 4 & 9 & 13 & 59.46 \\
\hline Analysis of competitive position & 6 & 4 & 3 & 11 & 13 & 64.86 \\
\hline Value chain analysis & 7 & 3 & 8 & 11 & 8 & 51.35 \\
\hline Product/Service life cycle analysis & 8 & 3 & 6 & 11 & 9 & 54.05 \\
\hline Analysis of competitors' strengths and weaknesses & 6 & 3 & 3 & 9 & 17 & 70.27 \\
\hline
\end{tabular}

Note: In Table 2, U1 means never, U2 means Rare, U3 means Sometimes U3, U4 means often and U5 means very often, and $\mathrm{U} 4$ and $\mathrm{U} 5$ form the relative total percentage of frequency of use. 


\subsubsection{Budgeting system}

The literature on management accounting stresses that budgeting is an essential technique for planning and controlling the activities of an organization (Drury et al., 1993). Table 2 shows that budgeting for controlling cost $(81.08 \%)$ and budgeting for planning $(72.97 \%)$ are the most adopted budgeting techniques. Of the seven budgeting techniques listed, obviously the Zero-Based Budgeting (ZBB) is the least adopted (29.73\%). Activity-Based Budgeting (ABB) $(64.86 \%)$ and budgeting for long term run $(51.35 \%)$ seem to be moderately adopted whiles flexible budgeting (48.65\%) and budgeting with 'what if analysis' appear to have little extend of use at Scancom Limited.

\subsubsection{Performance evaluation system}

Table 2 indicates $49.03 \%$ use of performance evaluation measures with uptakes across categories varying from a minimum of $24.32 \%$ up to $75.68 \%$. Managers at Scancom Limited shows low significant uptakes of most performance evaluation measures. Among seven wide performance measures listed, financial measures, non-financial measures related to customers, non-financial measures related to employees, non-financial measures related to operations and innovation, economic value added (EVA), total quality management (TQM) and benchmarking; $75.68 \%$ of the respondents scored financial measures as the highly used performance measures. In contrast, EVA $(24.32 \%)$ is the least considered used performance evaluation practice at Scancom Limited.

The uptake based on frequency of use is more varied and exhibits greater differences in application rates of performance measures especially between financial and non-financial measures. Non-financial measures, relating to employees $(45.95 \%)$, non-financial measures related to customers $(56.76 \%)$, non-financial measures related to operations and innovation $(51.35 \%)$ are often or very frequently used. Benchmarking is moderately used with over half of total respondents claiming frequent or very frequent adoption of its adoption at Scancom Ltd.

\subsubsection{Information for Decision making system}

The overall uptake of decision support system is very low. The average adoption rate of decision making systems is less than $50 \%$ of total average responses. The responses percentages range is between $29.73 \%$ and $67.57 \%$. This finding clearly suggests that MTN Ghana is more likely to use a more sophisticated approach to management accounting.

Within the Information for Decision making System, the most used technique is customer profitability analysis (67.57\%). Stock control model (51.35\%), free cash flow calculation $(56.76 \%)$ and product profitability analysis $(54.05 \%)$ are adopted by a slightly lower percentage of those respondents who made some use of decisions support systems. Cost-volume-profit analysis is the least uptake of all decision support tools. Meanwhile discounted cash flow technique is adopted by $35.14 \%$. This result suggests that $35 \%$ of respondents more frequently use discounted cash flow method for decision making.

\subsubsection{Strategic analysis (SA)}

Table 2 indicates that the overall relative uptake of individual strategic MAPs is high as reported by respondents, representing $58.48 \%$ of the five MAPs components. Of the eight techniques, analysis of competitors' strengths and weaknesses is most frequently used (70.27\%). Shareholder value is the least used Strategic Analysis tool, taking about $45.95 \%$ of relative usage within Strategic Analysis. Long range forecasting, and product/service life cycle (54.05\%), value chain analysis (51.35\%) divisional analysis (67.57\%), and analysis for competitive position (64.86\%) are often or very often used at Scancom Limited. Long range forecasting (89.19\%) and analysis of competitors' strengths and weaknesses $(86.49 \%)$ are highly beneficial.

\subsubsection{Reasons for Adoption of Management Accounting Practices}

The respondents were asked to score the reasons for the increased interest in cost and management accounting practices on a Likert scale of 1 (completely disagree) to 5 (completely agree). A list of reasons was provided for the respondents so that they evaluated each. The results of descriptive analysis are presented in Figure 2. It shows that global competition is the primary reason for the adoption of management accounting practices with a mean rating of 3.98. This is followed by increasing costs $($ mean $=3.38)$ and economic crises (mean $=3.38)$. Decreasing in profitability (mean $=3.08$ ) shows a low mean and based on t-test it cannot be considered an important reason for use of MAPs. Political pressures introduced by the researcher surprisingly indicate a deadlock position $(\operatorname{mean}=3)$. Economic crises which hit companies from time to time are also important reason for the increased interest in management accounting. 


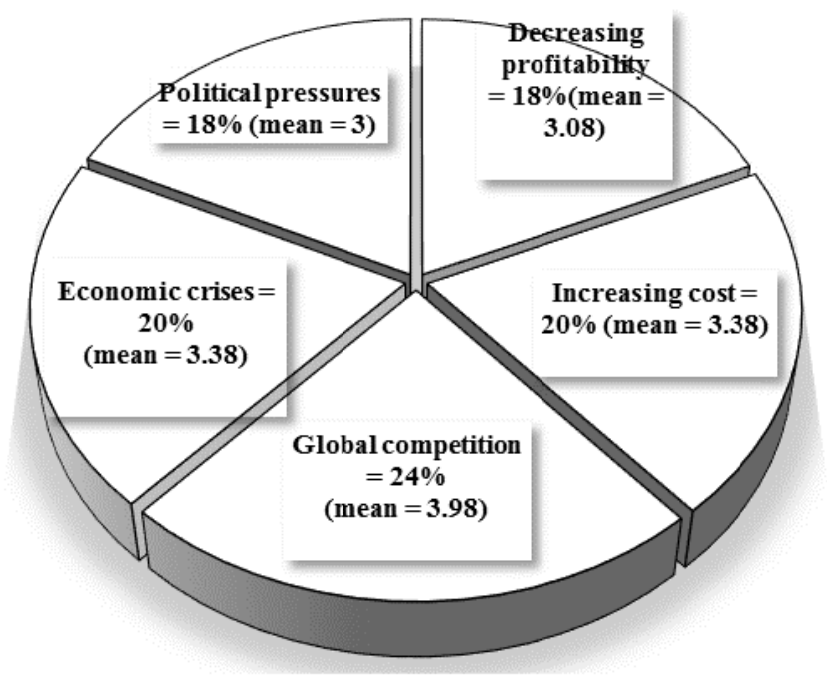

Figure 2. Reasons for adoptiong MAPs

\section{Discussion and Implication of Results}

\subsection{Extent of Use of Management Accounting Practices}

Generally, comparing the various MAPs as contained in Table 2, the extent of use of all management accounting practices measured revealed that budgeting for planning and cost controlling and financial measures as well as analysis of competitive strength are the widely used techniques. EVA on the other hand indicated very low adoption rate. Decision making tools indicated low usage and benefit responses whereas strategic analysis showed a high uptake level and benefit. Traditional techniques mainly from budgeting systems, performance evaluation and costing systems categories showed a high adoption and benefit results than recent techniques in the same class. This confirms the findings of Abdel-Kader and Luther (2006), Chenhall and Langfield-Smith (1998) and Pierce and O'Dea (1998) that, although there is an increase in usage of modern MAPs, the use of basic or traditional MAPs is still dominant in most firms.

It is argued that high acceptance of traditional techniques may be attributed to the fact that information and expertise relating to these measures is the most readily available as opposed to that relating to modern management accounting techniques. However modern tools for strategic analysis for example analysis for competitive position and analysis for competitors' strengths and weaknesses indicated better results than some of the tradition tools. As postulated by Abdel-Kader \& Luther (2006), the uptake of new or recent developed techniques will have better popularity in the future.

The result is consistent with most of the previous literature relating to management accounting in developing countries (see for example, Joshi, 2001; Phadoongsitthi, 2003; and El-Ebaishi et al., 2003). A significant uptake of traditional MAPs within the telecoms may be attributed to the fact that information on these measures is more readily available. Nevertheless modern management accounting techniques such as $\mathrm{ABB}, \mathrm{ABC}$, divisional analysis, industry analysis and analysis of competitors also showed a very significant improvement over previous studies (for example, Joshi, 2001; Abdel-Kader and Luther, 2006; Paggios and Pavlatos, 2009; Ahmad, 2012).

\subsubsection{Costing system}

The results indicate that both separation of cost and $\mathrm{ABC}$ techniques are equally used. This response is perhaps due to the nature of industry and as explained in literature, the international communication guide laid emphasis on $\mathrm{ABC}$ as a cost allocation method in telecommunication industries. However, previous studies indicated low adoption rate and the rationale is as explained earlier.

The frequency or otherwise adoption rate of $\mathrm{ABC}$ at Scancom Limited reflects an overwhelming application and popularity, which might be due to what Major and Hopper (2005) describe as "for internal management" and "external regulation":

The result obtained for extent of use of costing systems is at variance with previous studies. The dissimilarities are 
probably explained by differences in type of industry and respondents background. The use of $\mathrm{ABC}$ costing among respondents in the present study is higher than for previous studies. For example, Joshi (2001) found that the uptake of $\mathrm{ABC}$ only up to $20 \%$ among respondents. Paggios and Pavlatos (2009) in their studies on Greek hospitality industry scored $\mathrm{ABC} 23.5 \%$ with respect to frequency of usage. A much lower rate of use of $\mathrm{ABC}(10 \%)$ was attained in the study of MAPs in UK food and drinks industries by Abdel-Kader and Luther (2008). This current study result is relatively the same as that of Chenhall anad Langfiel-Smith (1998) who reported 56\% adoption rate (but classified as low adoption rate). The position of the current research on ABC (54.05\%) may be influenced by the respondents mix as explained earlier. Studies by Green and Amenkhienan (1992) and Hrisak (1996) claimed that around $50 \%$ of survey respondents firms used $\mathrm{ABC}$ to some extent but again this is not the same as the percentage of those respondents making some use of ABC.

Separation of cost (variable costing) scored (54.05\%) for extent of use is higher than the $48 \%$ reported by Abdel-Kader and Luther (2008), and the 43.5\% in Paggios and Pavlatos (2009), the 45\% in Ahmad (2012), Chenhall and Langfield-Smith (1998) reported 76\% usage rate for Separation of cost, which was though higher than this current study, but categorized as low. Meanwhile both in India and Thailand the use of variable costing was found in more than 50\% of firms (Joshi, 2001; Phadoongsitthi, 2003).

Departmental overhead rates (absorption costing) scored (62.16\%) higher than all the costing systems studied. However this is lower than the scores obtained by Chenhall and Langfiel-Smith (2008) 80\% (but categorized low adoption in their findings). Joshi (2001) recorded 50\% for absorption costing in terms of its usage and Abdel-Kadel and Luther (2008) presenting 13\% as utilization rate. Target costing under this current study yielded a higher result (40.54\%) than those obtained in previous studies, (Chenhall and Langfield-Smith, 1998 (38\%); Joshi, 2001 (35\%); Abdel-Kadel and Luther, 2008 (24\%)). Transfer pricing is a costing method primary for processing concern. This current study recorded transfer pricing as the least used costing MAPs of all costing systems studied, representing $21.62 \%$ relative uptake. This confirms the conclusion of Uyar (2010) which suggests that transfer pricing is least used by organisations.

Overall, it can be concluded that departmental overhead rate is the most widely employed cost allocation method by MTN Ghana. There is a significant uptake for ABC, separation of cost and target costing under this study than most previous researches. Thus, the use of cost systems by MTN Ghana is relatively low.

\subsubsection{Budgeting}

The extensive use of budgeting for planning and budgeting for controlling cost are consistent with those reported in Chenhall and Langfield-Smith (1998), Joshi (2001) and Paggios and Pavlatos (2009) who indicated that budgeting for planning and budgeting for controlling cost are widely employed in organisations. Abdel-Kader and Luther (2006) studies similarly reported that budgeting for planning (83\%) and budgeting for controlling (73\%) are frequently used by firms.

The significant use of flexible budgeting is consistent with Ahmad et al. (2003), who conducted a study among Malaysian firms and found that flexible budgeting has been widely implemented among those firms in Malaysia that use budgeting. Our finding of result $48.65 \%$ usage or uptake of flexible budgeting is similar to the findings of Drury et al. (1993), who found that $42 \%$ of UK firms adopted flexible budgeting which is in line with the $40 \%$ reported by total respondents of this study. A similar result was reported by Pierce and O'Dea (1998) and Szychta (2002). However results from Abdel-Kader and Luther (2008) showed 32\% of respondents who use flexible budgeting. This current study showed a higher uptake of flexible budgeting than previous studies indicated above. Meanwhile, the low uptake of ZBB is consistent with study by Joshi (2001) who found out that only 5\% of Indian firms employed ZBB. Similarly Szychta (2002) found that only $28 \%$ companies in her survey utilized this technique.

Overall, the results show that MTN Ghana make use of budgeting systems and emphasize the traditional budgeting techniques or systems which still remain highly adopted and beneficial to industries. This result answers the research question "Are the traditional management accounting practices still relevant and often used?" Paggios and Pavlatos (2009) concluded that traditional budgeting practices provided higher benefits than contemporary budgeting tools.

\subsubsection{Performance evaluation systems}

The general use of financial measures of performance is consistent with other studies (see for example, Joshi (2001); Phadoongsitthi (2003); Abdel-Kader and Luther (2006); and Jusoh and Parnell (2008). Phadoongsitthi (2003) reported that most Thai firms still focus on financial performance measures such as budget variance analysis, return on investment, cash flow return on investment, and divisional profit. Similarly Jusoh and Parnell (2008) revealed that many Malaysian manufacturing firms placed a greater emphasis on financial rather than non-financial measures. 
With regard to non-financial performance measures, measures related to operations and innovation, and customers are found to have a high adoption rate among the majority of respondents in previous studies (e.g., Abdel-Maksoud et al., 2005; Chenhall \& Langfield-Smith, 1998; Phadoongsitthi, 2003). Phadoongsitthi (2003) indicated that Thai firms increase their focus on customer satisfaction and on-time delivery when considering performance.

Likewise Abdel-Maksoud et al. (2005) indicated that the overwhelming majority of UK manufacturing companies measure performance in terms of delivery timeliness, number of complaints from customers and customer satisfaction. Abdel-Kader and Luther (2006) indicated non-financial measures related to employees as $11 \%$ of responses and this is lower than current result (45.95\%). Thus adoption of non-financial measures related to employees at Scancom Limited is high compare to Abdel-Kader and Luther (2006). Meanwhile the current report for non-financial measures related to employees is consistent with those of Paggios and Pavlatos (2009).

The findings suggest that Scancom Limited uses non-financial performance measures, related to operations and innovations and to customers more often than employee focused. The lower use of non-financial measures is consistent with prior research but may also be attributed to the nature and size of the firm. Besides as non-financial measures are more recently-developed measures, their adoption may not be as widespread as opposed to the traditional measures which have long been used by many firms. Thus these reasons might explain the low adoption of non-financial measures found in this study. Meanwhile considering previous studies (Abdel-Kader, 2006; Paggios \& Paclatos, 2009) this current study indicated an improvement on adoption or use of non-financial measures. The findings also suggest that performance evaluation system in general is important at MTN Ghana.

\subsubsection{Information for decision making systems}

The percentage uptake of customer profitability analysis overall is at the low end that reported in previous research findings. For example, Chenhall and Langfield-Smith (1998), Joshi (2001) and Drury and Tayles (2006) reported that customer profitability technique was used by more than $80 \%$ of firms in their studies. This is reasonable as the sample is taken from relatively small-size firms, whereas previous findings mostly included large companies. The product profitability analysis was also frequently reported moderate in previous studies (Chenhall and Langfield-Smith (1998).

Surprisingly, Paggios and Pavlatos (2009) reported 94.1\% for adoption of product profitability analysis which is much higher than this current study. Also their report indicated that product profitability analysis was widely used than customer profitability analysis. This current finding suggests that focus is much placed on customers rather than products or services.

Cost-volume-profit (CVP) analysis is another tool which is frequently reported in previous studies. These studies consistently reported infrequent use of CVP which is in line with the result of this study. For example in Poland, Szychta (2002) found that this technique was used by just under 50\% respondents. Meanwhile Abdel-Kader and Luther (2006) found that just under $40 \%$ of U.K firms often or very often utilized CVP.

Capital investment analysis techniques have been widely investigated. The present study indicates a low use of all capital investment tools especially discounted cash flow based analyses and this is consistent with previous studies (Abdel-Kader \& Luther, 2006; Shields et al., 1991). Abdel-Kader and Luther (2006) reported use of Net Present Value (NPV) and Internal Rate of Return (IRR) at between 9\% and 19\%. Meanwhile discounted cash flow technique was reported as lowly important in previous studies by Abdel-Kader and Luther (2006). In their study, this technique was rated as $87 \%$ of responding firms.

Overall, it can be concluded that only a moderate number of respondents make use of decision making tools beyond product profitability and customer profitability analysis, and that MTN Ghana infrequently employ CVP and capital investment techniques. Nevertheless it is evident that decision making tools are important at MTN Ghana. It can also be concluded that traditional decision making tools such as stock control models and discounted cash flow technique are still used and also beneficial to organizations and this confirms the report by Triest \& Elshahat (2007).

\subsubsection{Strategic analysis (SA)}

Table 2 suggests that competitors' strengths and weaknesses, divisional analysis and analysis of competitive position are the top three techniques used by MTN Ghana. It is noted that the overall uptake and the frequency of use is low (58.45\%) but its relative benefit appears to be high in organisations (Abdel-Kader \& Luther, 2006).

In term of product/service life cycle analysis, the present result is consistent with studies by Chenhall and Langfield-Smith (1998) and Joshi (2001). However Abdel-Kader and Luther (2006) reported that only 5\% UK firms often or very often employed this analysis. Joshi (2001) reported that a quarter of Indian firms used value chain 
analysis, and Abdel-Kader and Luther (2006) found that just under a quarter of British firms often and very often employed that technique.

Overall, the usage of SA practices is not as low as reported by Abdel-Kader and Luther (2006). Abdel-Kader and Luther (2006) indicated that high scoring of analyses of value chain, competitive position and competitors' strengths and weaknesses will become more widespread and frequent. Indeed SA included in this current study revealed an over whelming increase in uptake and benefit comparative to some previous studies Guilding et al., (2000), Joshi (2001), Paggios and Pavlatos (2009) and Ahmad (2012). Chenhall and Langfield-Smith (1998) also reported a relatively low use of value chain analysis in their studies. Abdel-Kader and Luther (2006) revealed that competitive position analysis is frequently used by $33 \%$ of British firms which is very different from the result in this study which is $64.86 \%$. This current results suggest that the use of analysis of competitive position is becoming much popular in industries in that its benefits ascribed are higher than as reported by Abdel-Kader and Luther (2006).

\subsection{Reasons for adoption of MAPs}

In Uyar's (2010) study, all four reasons assigned were highly accepted by respondents as it is the case of this study. The current results suggest that profitability of an organization will be maximized when there is effective cost management (control cost). Thus if there is a reduced cost of operation where revenue remains constant then profit will increase. Economic crises invariably affect operational cost (economic thunder or turbulence will cause a possible increase in cost of operations).

\section{Limitations and Future Research}

This study is limited in two ways. First, it is limited to only one telecom company in Ghana. Despite the fact that this company is the leading telecom operator in Ghana, the findings of the study may not fully reflect MAPs in the Ghana and for that all companies in developing countries. Second, the study is limited in sample size. It recommended future research should increase the scope of the research by including more companies and the sample size. Moreover, future research could examine the role of respondents' background data or profile on their adoption of MAPs. In addition, the nature of the reliance between traditional and recently-developed MAPs needs further investigation. Other areas for future research are conditions for effective implementation of strategic analysis and decision making techniques within telecoms as well as a longitudinal study of management accounting change within telecoms.

\section{Conclusion}

Competitive activities either domestic or global couple with economic and cost issues have become crucial concerns for the mobile telecommunication companies in Ghana. The industry is striving with the quest to maintain its competitive edge and also to run a cost effective and sound profitable venture. Research has shown that MAPs have a role in ensuring that the management of a firm is efficient and effective and may also improve performance. The result is consistent with most of the previous literature relating to management accounting in developing countries (e.g., Joshi, 2001; Phadoongsitthi, 2003; El-Ebaishi et al., 2003). A significant uptake of traditional MAPs within the telecoms may be attributed to the fact that information on these measures is more readily available. Nevertheless modern management accounting techniques such as $\mathrm{ABB}, \mathrm{ABC}$, divisional analysis, industry analysis and analysis of competitors also showed a very significant improvement over previous studies (e.g., Abdel-Kader \& Luther, 2006; Ahmad, 2012; Joshi, 2001; Paggios and Pavlatos, 2009).

The results show that the most used category of MAPs is strategic analysis practices, which is not as low as reported in previous research. The next most used MAPs by MTN Ghana are related to budgeting system, implying that the use of traditional budgeting techniques or systems still prevalent in network industries. Moreover, the results show that MTN Ghana relies more on financial measures than non-financial measures. Overall, it can be concluded that only a moderate number of respondents make use of decision making tools beyond product profitability and customer profitability analysis. The use of costing systems by MTN Ghana is quite low, but the prevalent among them are departmental overhead rate and Activity-based Costing. The most important reasons for the firm's adoption of MAPs are global competition, increasing cost and economic crises.

Theoretically, this papers adds to the existing literature on the extent to which MAP are used by business organisations, especially in the telecommunication industry in a developing economy perspective, which is under-researched. In particular it confirms a number of previous studies that most firms still adopts traditional MAPs and also provides empirical insights into the reasons for firms' adoption of these MAPs. Managerially, this papers provides strategic directions to regulators like Telecom Chambers for enhancing of existing training programs. 


\section{References}

Abdel-Kader, M., \& Luther, R. (2006). Management accounting practices in UK food and Drinks Industry. London: CIMA.

Abdel-Kader, M., \& Luther, R. (2008). The impact of firm characteristics on management accounting practices: A UK-based empirical analysis. The British Accounting Review, 40, 2-27. http://dx.doi.org/10.1016/j.bar.2007.11.003

Abdel-Maksoud, A., Dugdale, D., \& Luther, R. (2005). Non-financial performance measurement in manufacturingcompanies. The British Accounting Review, 37(3), 261-297.

Ahmad, K. (2012). The Use of Management Accounting Practices in Malaysian SMES. University of Exeter.

Banker, R.D., Potter, G., \& Srinivasan, D. (2000). An empirical investigation of an incentive plan that includes non-financial performance measures. The Accounting Review, 75, 65-92. http://dx.doi.org/10.2308/accr.2000.75.1.65

Bjørnenak, T. (1997). Diffusion and accounting: the case of ABC in Norway. Management Accounting Research, 8, 3-17. http://dx.doi.org/10.1006/mare.1996.0031

Cadez, S., \& Guilding, C. (2008). An exploratory investigation of an integrated contingency model of strategic management accounting. Accounting, Organizations and Society, 33, 836-863. http://dx.doi.org/10.1016/j.aos.2008.01.003

Chenhall, R. H., \& Langfield-Smith, K. (1998). Adoption and benefits of management accounting practices: an Australian study. Management Accounting Research, 9(1), 1-19. http://dx.doi.org/10.1006/mare.1997.0060

Christensen, H. B., \& Nikolaev, V. V. (2013). Does fair value accounting for non-financial assets pass the market test?. Review of Accounting Studies, 18(3), 734-775. http://dx.doi.org/10.1007/s11142-013-9232-0

CIMA (2005). Management Accounting Official Terminology. The Chartered Institute of Management Accountant. Cooper, D. R. \& Schindler P. S. (2006). Business Research Methods. New York: McGraw-Hill Irwin.

Cooper, D. R. \& Schindler P. S. (2006). Business Research Methods. New York: McGraw-Hill Irwin.

Dossi, A., \& Patelli, L. (2010). You learn from what you measure: financial and non-financial performance measures in multinational companies. Long Range Planning, 43(4), 498-526. http://dx.doi.org/10.1016/j.lrp.2010.01.002

Drury, C. \& Tayles, M. (2006). Profitability analysis in UK organizations: An exploratory study. The British Accounting Review, 38, 405-425. http://dx.doi.org/10.1016/j.bar.2006.05.003

Drury, C., \& Tayles, M. (1994). Product costing in UK manufacturing organizations. European Accounting Review, 3(3), 443-470. http://dx.doi.org/10.1080/09638189400000031

Drury, C., Braund, S., Osborne, P., \& Tayles, M. (1993). A survey of management accounting practices in UK manufacturing companies. Chartered Association of Certified Accountants.

El-Ebaishi, M., Karbhari, Y., \& Naser, K. (2003). Empirical evidence on the use of management accounting techniques in a sample of Saudi manufacturing companies. International Journal of Commerce and Management, 13(2), 74-101. http://dx.doi.org/10.1108/eb047467

Fruitticher, L., Stroud, N., Laster, J., \& Yakhou, M. (2004). USA budget practices case studies. Managerial Auditing Journal, 20(2), 171-178.

Gomes, C.F., Yasin, M.M., \& Lisboa, J.V. (2004). An examination of manufacturing organizations' performance evaluation; Analysis, implications and a framework for future research. International Journal of Operations \& Production Management, vol. 24(5) 488-513. http://dx.doi.org/10.1108/01443570410532551

Green, F.B. \& Amenkhienan, F.E. (1992). Accounting innovations: a cross-sectional survey of manufacturing firms. Journal of Cost Management, 6, 58-64.

Guilding, C., Cravens, K.S., \& Tayles, M. (2000). An international comparison of strategic management accounting practices. Management Accounting Research, 11, 113-135. http://dx.doi.org/10.1006/mare.1999.0120

Hair, J. F., Black, W. C., Babin, B. J., \& Anderson, R. E. (2010). Multivariate Data Analysis, Englewood Cliffs, NJ: Prentice Hall.

Hair, J.F.J., Money, A.H., Samouel, P., \& Page, M. (2007). Research Methods for Business. U.S: Wiley. 
Hall, M. (2008). The effect of comprehensive performance measurement systems on role clarity, psychological empowerment and managerial performance. Accounting, Organizations and Society, 33, 141-163. http://dx.doi.org/10.1016/j.aos.2007.02.004

Hermes, N., Smid, P., \& Yao, L. (2007). Capital budgeting practices: A comparative study of the Netherlands and China. International Business Review, 16, 630-654. http://dx.doi.org/10.1016/j.ibusrev.2007.05.002

Hrisak, D. (1996). The controller as business strategist. Management Accounting, 78(6), 48-49, retrieved on 19 June 2011 from http://www.harzing.com/download/resprates.pdf

Ismail, T.H. (2007). Performance evaluation measures in the private sector: Egyptian practice. Managerial Auditing Journal, 22(5), 503-513. http://dx.doi.org/10.1108/02686900710750775

Ittner, C.D., \& Larcker, D.F. (1998). Are nonfinancial measures leading indicators of financial performance? An analysis of customer satisfaction. Journal of Accounting Research, 36, 1-35. http://dx.doi.org/10.2307/2491304

Ittner, C.D., Lanen, W.N., \& Larcker, D.F. (2002). The association between activity-based costing and manufacturing performance. Journal of Accounting Research, 40 (3), 711-726. http://dx.doi.org/10.1111/1475-679X.00068

James, P. C. (2012). The Application of Innovative Management Accounting Principles for Enhancing Profitability and Competitiveness: An Exploratory Study of Jamaican Manufacturers. International Journal of Business and Social Research, 2(6), 47-60.

Joshi, P. L. (2001). The international diffusion of new management accounting practices: the case of India. Journal of International Accounting, Auditing and Taxation, 10(1), 85-109. http://dx.doi.org/10.1016/S1061-9518(01)00037-4

Jusoh, R. \& Parnell, J.A. (2008). Competitive strategy and performance measurement in the Malaysian context. An exploratory study. Management Decision, 46 (1), 5-31. http://dx.doi.org/10.1108/00251740810846716

Langfield-Smith, K. (2008). Strategic management accounting: how far have we come in 25 years?. Accounting, Auditing \& Accountability Journal, 21 (2), 204-228. http://dx.doi.org/10.1108/09513570810854400

Lazaridis, I. T. (2004). Capital budgeting practices: A survey in the firms in Cyprus. Journal of Small Business Management, 42(4), 427-433.

Lin, Z. J., \& Yu, Z. (2002). Responsibility cost control system in China: the Han Dan experience. Asia Pacific Business Review, 9(1), 59-78. http://dx.doi.org/10.1080/713999171

Lord, B.R. (1996). Strategic Management Accounting: The emperor's new clothes?. Management Accounting Research, 7, 347-366. http://dx.doi.org/10.1006/mare.1996.0020

Lukka, K. \& Granlund, M. (1996). Cost accounting in Finland: current practice and trends of development. The European Accounting Review, 5, 1-28. http://dx.doi.org/10.1080/09638189600000001

Lyne, S.R. (1988). The role of the budget in medium and large U.K. companies and the relationship with budget pressure and participation, Accounting and Business Research, 18(71), 195-212. http://dx.doi.org/10.1080/00014788.1988.9729367

Major, M. J. M. F. (2012). Management Accounting Change in the Portuguese Telecommunications Industry. Global Advanced Research Journal of Management and Business Studies Vol. 1 (4), 115-125.

Major, M., \& Hopper, T. (2005). Managers divided: Implementing ABC in a Portuguese Telecommunications Company. Management Accounting Research, 16, 205-229. http://dx.doi.org/10.1016/j.mar.2005.01.004

National Communication Authority (2013). Telecom voice subscription trends. Retrieved from http://www.nca.org.gh/downloads/Telecom_Voice_Subscription_July_2013.pdf on August 20, 2013.

Nimako, G. S., Azumah, K. F., Donkor, F., \&Adu-Brobbey, V. (2010). Overall Customer Satisfaction in Ghana's Mobile Telecommunication Networks: Implications for Management and Policy. African Technology Development Forum, 7(3/4), 35-49.

Nimako, S.G. (2012). Linking quality, satisfaction and behaviour intentions in Ghana's mobile telecommunication industry. Eur. J. Bus. Manag., 4(7), 1-17.

Paggios, I. \& Pavlatos, O. (2009). Management accounting practices in the Greek hospitality industry. Managerial auditing journal, 24(1), 81-98. http://dx.doi.org/10.1108/02686900910919910 
Phadoongsitthi, M. (2003). The role of management accounting in emerging economies: An empirical study of Thailand. Ph.D Thesis, University of Maryland, College Park.

Pierce, B. \& O`Dea, T. (1998). Management accounting practices in Ireland - The preparers' perspective Research Paper Series Paper, no. 34.

Sharkar, M. Z., Sobhan, A., \& Sultana, S. (2006). Management Accounting Development and Practices in Bangledesh. BRAC University Journal, 3(2), 113-124.

Shields, M. D., Chow, C. W., Kato, Y., \& Nakagawa, Y. (1991). Management Accounting Practices in the U.S. and Japan: Comparative Survey Findings and Research Implications. Journal of International Finance Management and Accounting, 3(1), 61-77. http://dx.doi.org/10.1111/j.1467-646X.1991.tb00091.x

Siguenza-guzman, L., Van den Abbeele, A., Vandewalle, J., Verhaaren, H., \& Cattrysse, D. (2013). Recent evolutions in costing systems: A literature review of Time-Driven Activity-Based Costing. Review of Business and Economic Literature, 58(1).

Sleihat, N., Al-Nimer, M., \& Almahamid, S. (2012). An Exploratory Study of the Level of Sophistication of Management Accounting Practices in Jordan. International Business Research, 5(9), p217. http://dx.doi.org/10.5539/ibr.v5n9p217

Sulaiman, M. Ahmad, N.A.N. \& Alwi, N. (2004). Management accounting practices in selected Asian countries. Managerial Auditing Journal, 19 (4), 493-508. http://dx.doi.org/10.1108/02686900410530501

Szychta, A. (2002). The scope of application of management accounting methods in Polish enterprises. Management Accounting Research, 13, 401-418. http://dx.doi.org/10.1006/mare.2002.0198

Uyar, A. (2010). Cost and Management Accounting Practices: A Survey of manufacturing companies . Eurasian Journal of Business and Economics , 3(6), 113-125.

Van Triest, S. V., \& Elshahat, M. F. (2007). The use of costing information in Egypt: a research note. Journal of Accounting \& Organisation Change, 3(3), 329-343. http://dx.doi.org/10.1108/18325910710820328

Vazakidis, A., \& Karagiannis, I. (2011). Activity-based management and traditional costing in tourist enterprises (a hotel implementation model). Operational Research, 11(2), 123-147. http://dx.doi.org/10.1007/s12351-009-0049-3

Yoshikawa, T. (1994). Some aspects of the Japanese approach to management accounting', Management Accounting Research, 5, 279-89. http://dx.doi.org/10.1006/mare.1994.1017 